\title{
The Negative Effects of Undergraduate Placement Examination of English (LYS-5) on ELT Students in Turkey
}

\begin{tabular}{|c|c|}
\hline Department of Engl & $\begin{array}{l}\text { Ayșe SAYIN }{ }^{*}, \text { Musa Mükerrem ASLAN } \\
\text { inguage Teaching (ELT), Canik Basarı University, Samsun, Turkey }\end{array}$ \\
\hline Article history & This study aims to explore the perceptions of English Language Teaching \\
\hline Received: & department freshman students in Turkey towards Undergraduate \\
\hline & Placement Examination of English termed LYS-5 and display the \\
\hline Recei & \\
\hline 02.03 & $\begin{array}{l}\text { examination is taken by thousands of Turkish high school seniors every } \\
\text { year who would like to be language teachers or professionals. However, }\end{array}$ \\
\hline $\begin{array}{l}\text { Accepted: } \\
04.03 .2016\end{array}$ & $\begin{array}{l}\text { the accuracy and effectiveness of this exam has always been an issue. } \\
\text { Major criticism to the exam structure is that students who prepare for the }\end{array}$ \\
\hline Key v & helmingly focus on grammar, vocabulary and reading, and \\
\hline $\begin{array}{l}\text { English language exam, } \\
\text { standardized tests, } \\
\text { undergraduate placement } \\
\text { examination (LYS-5), } \\
\text { university entrance exam } \\
\text { (UEE), language assessment }\end{array}$ & $\begin{array}{l}\text { they tend to disregard other language skills (Ögün, 2010). Considering } \\
\text { the problems in the structure of the test and taking the importance of the } \\
\text { examination for students into account, a survey was prepared and } \\
\text { delivered to } 74 \text { ELT students from two different universities. The data } \\
\text { results revealed the necessity of a newly constructed LYS-5 in Turkey by } \\
\text { taking the worldwide accepted English examinations into account. The } \\
\text { findings profoundly reflect that there are neglected major skills which are } \\
\text { excluded not only from the LYS-5 exam but also from the studies and in- } \\
\text { class practices of the students and teachers. Language examinations need } \\
\text { to be improved as the teaching methods and learning processes differ in } \\
\text { the course of time. While the sphere of the study is not very wide, it is } \\
\text { aimed to contribute to the existing studies, and to emphasize the } \\
\text { emergency of the problem. }\end{array}$ \\
\hline
\end{tabular}

\section{Introduction}

With the rapid increase in the number of youth in Turkey, the need for university education and applications for universities have increased, too. Thus, an eliminatory and selective exam was required. As it is considered that universities are science and research centers (Azar, 2010), University Entrance Exam takes its essential place among high stakes tests in Turkey. When taken into consideration that universities serve as a bridge between educational and business life, it is an inevitable fact that students take the entrance exam more seriously than anything during that period.

The exam, which is conducted by Student Selection and Placement Center (ÖSYM), consists of two steps: Higher Education Examination (YGS) and Undergraduate Placement Examination (LYS). These standardized exams are to be taken by any students wanting to be placed at a university in Turkey. The former one is composed of 160 multiple choice 
questions testing 4 different subjects, of Turkish language, mathematics, physical science and social science with 40 questions for each. The latter is more selective than the previous since it tests students depending on the profession they want. A student, who is a prospective undergraduate of English Language Teaching (ELT) department, is given an 80-question exam in English. However, it is still questionable whether it is as selective as the other sample exams carried out in other countries. Major criticism to it is that students who prepare for the exam overwhelmingly focus on grammar, vocabulary and reading, and they tend to disregard other language skills (Özgün, 2010).

It is expected from the students studying in foreign language training departments to know the language they major at a certain level (Demirel, 1991). However, as a result of the testing style, students are likely to focus only on reading when getting ready for LYS by ignoring other three skills as Özgün (2010) mentioned above. When placed at an ELT department, students will have to write and communicate in English, which requires both listening and speaking though the anxiety they experience may have a debilitating impact on their ability to speak (Philips, 1992). Given that language is the most vital point of a culture (Şahin, 2007), imposing one skill testing LYS exam on future teachers of that culture may end up in horrible circumstances.

In the light of these predictions, this study will investigate the effects of LYS examination on English Language Teaching (ELT) undergraduates, and their perceptions and comments on the exam with the following research questions;

(1) Is LYS exam comprehensive enough to measure the basic skills necessary to learn a foreign language?

(2) Do ELT students feel competent enough for their department in their freshman year at the college after preparing for LYS exam?

(3) What kind of changes are necessary in the LYS exam in order to measure the competency levels of language students?

\section{Literature Review}

University Entrance Exam has been restructured several times in the previous decades in Turkey (Dinç, 2014). Lastly, it was decided to move into a new examination system in 2010. The double-stage exam has been conducted once a year since then. Higher Education Examination (YGS), the first stage of the two, is generally held in the second week of March. All applicants are held responsible from the same common curriculum subjects, of Turkish language, science (biology, physics, chemistry), mathematics and social sciences (history, geography, philosophy). The number of questions asked is 160, and respectively the time given to finish the exam is 160 minutes, as well.

Although the impact of first stage (YGS) is less than the second stage on the final score in University Placement Examination, what makes it quite significant is that in order to participate in the second stage, an applicant needs to get the required score from YGS.

On the other hand, LYS, the second stage of the exam, is composed of 5 sessions, as LYS-1, LYS-2, LYS-3, LYS-4 and LYS-5. Contrary to YGS exam, the question number and time vary in the sessions of LYS. Applicants, attempting to attend a higher education institution, have to take at least two of these sessions in accordance with the department they want to choose (Koçak, 2012). However, it is exceptional for language learners. They are supposed to take only LYS-5 (foreign language examination) session in which they are asked 80 questions 
and given 80 minutes. Besides, the applicants have the opportunity to choose the language from a selection of languages offered.

The need of language examination may depend on several factors such as location, economic growth, commerce and growing population (Ağazade, Caner, Haspipoğlu \& Civelek, 2013). China, affected by these factors, has given high importance to foreign language education, especially English. Thus, English language education began to be taught at the early stages, starting from Grade-3 in primary schools. Furthermore, to put emphasis on the significance of English, it has been made a compulsory subject in the national university entrance exam for all types of universities and colleges (Cheng 2008). Moreover, English language skills are tested for all those seeking promotion in governmental, educational, scientific research, medical, financial, business and other government supported institutions (He, 2001).

Administered by National College English Testing Committee (NCETC), College English Test (CET) consists of three tests: Bank 4 (CET-4), Bank 6 (CET-6) and CET- Spoken English Test (CET-SET) (Zeng \& Cheng, 2008). CET has been restructured a few times since its emergence. The current system of CET includes all skills required for a language, of reading, listening, speaking and writing. (National College English Testing Committee, 2006). Of all skills, writing, which has three meta-functions: ideational, interpersonal and textual, is what Chinese students are mostly incapable of $(\mathrm{Li}, 2010)$.

Japan is another country trying to enhance the appropriateness of English examinations since it serves as a link with the West. There has been a lot of criticism in the last fifteen years on the quality and appropriateness of English language entrance examination in Japan (Brown \& Christensen, 1987; Brown, 1995a; Brown \& Kay, 1995 as cited in Brown, 2002). To illustrate, adding listening section on Japanese university English examinations was discussed in 1987 (Brown \& Christensen, 1987). Kellaghan and Greaney (1992) anticipated the use of various examination formats such as written, oral, aural and practical sections as a strategy to improve the test content in Japan (cited in Brown, 2002). The efforts to change the examination system has started in 2003, and with the reforms, the exam is partially adjusted to CLT (Communicative Language Teaching) approach.

Entrance examinations, in general, require too much knowledge about the language, but offer little or no opportunity to demonstrate ability to perform in English (Kenji, 1988). Language examinations need to be improved as the teaching methods and learning processes differ in the course of time. When there is a change in the curriculum, it is necessary to make changes in the testing system and to introduce new tests as the examples can be seen in China (Qi, 2005), in Japan (Buck, 1988; Watanabe, 1996), in Sri Lanka (Wall and Alderson, 1993), in Hong Kong (Cheng, 1997, 2005), in Israel (Shohamy, 1992) and in several other countries, as well (Karabulut, 2007). While the quality of language examinations conducted in other countries has been enhanced in the process of time, it is also highly essential for Turkey to implement a consistent change in foreign language tests by applying widely approved and accepted standards - especially for the LYS exam. For this reason, it can be asserted that the LYS exam needs content and format changes.

Implementing content changes to the foreign language standardized test may have different influence on students' performance which is due to the nature of the washback effect as indicated in a study of Andrews et al. (2002) carried out in China. However, as Wall (2000) points out, most of the studies done were on how the washback effect is related with the processes and methodologies teachers used more than paying attention to the 'product' of 
learning. Gates (1995) defines washback as the influence of testing on teaching and learning, and for him, if a test is substantial for the test taker, it is likely to induce a strong washback effect, and if it is not a significant test which does not take into consideration what happens in the language classroom, then, it triggers weak washback (Karabulut, 2007). LYS, in this sense, is a norm-referenced external test which directly affects the test takers; students get into the university based on the test results (Karabulut, 2007).

Hamp-Lyons (1997) states that 'claims about the impact of tests extend their influence well beyond the classroom, into school-wide or school district behaviors, on to the educational system as a whole,...' (pp.297), and gives an example:

There are two essential problems with standardized test... First, they fail to adequately measure important student learning. Even more important, their use has encouraged, or at least helped perpetuate, classroom practices that fail to provide high-quality education, particularly for children from low-income families. The reasons for this include:

- The multiple choice format

- Norm-referencing

- Making decisions using one test

- The use of these tests for accountability (FairTest, n.d.:1) (cited in Hamp-Lyons, 1997, pp. 297-298)

As for the influence of testing on teaching and learning, Alderson and Wall (1993) bring forward 15 hypotheses to describe its working mechanism (cited in Wang et al., 2014). These hypotheses are:

- A test will influence teaching

- A test will influence learning

- A test will influence what teachers teach

- A test will influence how teachers teach

- A test will influence what learners learn

- A test will influence how learners learn

- A test will influence the rate and sequence of teaching

- A test will influence the rate and sequence of learning

- A test will influence the degree and depth of teaching

- A test will influence the degree and depth of learning

- A test will influence attitude towards the content, method, etc., of teaching and learning

- Tests that have important consequences will have washback; conversely,

- Tests that do not have important consequences will have no washback

- Tests will have washback on all learners and teachers

- Tests will have washback effects for some learners and some teachers but not for others. (Karabulut, 2007, pp. 8, 9)

Considering the assertions of Hamp-Lyons (1997) as mentioned above and based on the hypotheses of Alderson \& Wall (1993), especially the items regarding 'learning', this study focuses on the effects of current LYS exam for the preparation of students from university exam to their related (ELT) field as well as the required changes in the content and format of LYS exam. 


\section{Methodology}

Considering the research questions of the study, the data were collected through the use of quantitative method and with questionnaire analysis. The questionnaire used for this study was adapted from 'College Student Survey' section of Karabulut (2007) with slight changes and selection of necessary items. The adapted questionnaire consisted of different question types ( 1 Yes-No, 3 Checklists, 3 Likert scale questions) which in total includes 9 items. While the items from 1 to 4 were used with the intention of collecting personal information about the participant students, the items from 5 to 9 were used to evaluate the perceptions of the attendees for University Entrance Examination (UEE) in order to find out what changes are necessary and how much UEE helps them through their education at their department. In the adapted questionnaire, items 5 and 6 were intended to be used to clarify the first research question of the study while item 7 was directly and explicitly used to measure the second question. Items 8 and 9 gave the related information for the research question three, and in general, the survey questions are aimed to collect the necessary data.

\section{Participants}

Participants were 74 Turkish freshmen students at the department of English Language Teaching all of whom met the criteria set. Among these students, 59 of them were female and 15 of them were male whose age ranges from 18 to 34 with a mean of 20.2. They were respectively selected from the two universities located in Samsun, Turkey.

\section{Data Results and Analysis}

The student questionnaire results are presented in frequency and percentile tables, and the given data were gathered by using SPSS analysis. Table 1 below gives the descriptions of the questionnaire item 5 which aimed to display whether students oriented their studies solely to the exam, and signifies the measures of "Yes - No" answers of the students.

Table 1. LYS-5 exam preparation results

\begin{tabular}{llcc}
\hline \multicolumn{4}{c}{ Q_5 - Did you only prepare for the language skills that are required on the } \\
\multicolumn{4}{c}{ LYS-5 examination? } \\
\hline & $\mathrm{N}$ & Mean & Std. Deviation \\
\hline & 72 & 1.2917 & 0.45772 \\
\hline Valid & \multicolumn{4}{c}{ Frequency } & Percentile (\%) \\
& No & 51 & 70.8 \\
Missing & Total & 21 & 29.2 \\
& System & 72 & 97.3 \\
Total & & 2 & 2.7 \\
\hline
\end{tabular}

As indicated in Table 1, 51 students (70.8\%) out of 72 with 2 missing answers said 'Yes', while 21 students $(29.2 \%)$ said 'No' to this question. The high frequency of the answer 'Yes' shows some skills are neglected during preparation for the exam.

Depending on the gathered results from questionnaire item 5, students were asked to state what kind of language activities they focused on during high school English classes. The obtained results were arranged in frequency and percentile table below by separating the included and excluded language skills accordingly with LYS-5 exam. 
Table 2. Frequencies of the language activities practiced in high school

\begin{tabular}{cccc}
\hline & Language Activities & Frequency & Percentile (\%) \\
\hline Skills that are not & Writing Essays & 12 & 14.9 \\
included in LYS-5 & Listening activities & 17 & 23 \\
examination & Speaking activities & 13 & 17.6 \\
\cline { 1 - 1 } Skills that are & Reading activities & 73 & 98.6 \\
required for LYS-5 & Vocabulary practice & 72 & 97.3 \\
examination & Grammar practice & 74 & 100 \\
& Practicing test-based questions & 74 & 100 \\
& General assessment tests & 67 & 90.5 \\
\hline
\end{tabular}

Students' checklist of the language skills and activities in Table 2 indicates that the skills (writing, listening and speaking) which are not included in the LYS-5 exam were practiced only by minority of students. The average results of students' answers for the excluded yet major language skills are $18.5 \%$ by 14 students, and $97.28 \%$ by 72 students for the required skills of the exam. The averages illustrate the high difference of the studied skills and given importance to the LYS-5 exam. It can also be stated that writing (12\%) is the most neglected skill in language learning and teaching process while grammar and test-based practice questions were highly emphasized $(100 \%)$. The noteworthy difference in the practice of exam-oriented skills and the excluded three language skills also displays the attitude towards language learning.

In the questionnaire item 7, the students were asked to indicate which of the skills and question types they focused in LYS-5 exam were helpful for their department (ELT). Table 3 below gives the response analysis and opinions of students on useful language sections.

Table 3. Frequencies of the useful language sections asked in LYS-5 for students' departmental studies

$\begin{array}{ccc}\text { Language Sections asked in LYS-5 } & \text { Frequency } & \text { Percentile (\%) } \\ \text { Grammar } & 53 & 78 \\ \text { Vocabulary } & 49 & 72.1 \\ \text { Reading } & 49 & 72.1 \\ \text { Translation } & 43 & 63.2 \\ \text { Close Tests } & 38 & 56 \\ \text { Sentence Completion } & 37 & 54.4 \\ \text { Odd one out } & 26 & 38.2 \\ \text { Dialogue Completion } & 38 & 56 \\ \text { All of them } & 22 & 32.4\end{array}$

The table explicitly indicates that grammar $(78 \%)$ is thought to be the most necessary and major skill for students' departmental studies which was followed by vocabulary (72\%) and reading $(72 \%)$ skills. While 'odd one out' question type was regarded as the least necessary question type (with $38 \%$ ), students' general attitude towards the essentiality of LYS-5 skills and question types also reflects their low opinion (32.4\%) about the exam.

Direct opinions of students on LYS-5 were analyzed through the use of Likert Scale which were illustrated in Table 4 below.

Table 4. Opinions of students on LYS-5 - frequency and percentile distribution 


\begin{tabular}{|c|c|c|c|c|c|c|c|c|c|}
\hline \multicolumn{10}{|c|}{ "I think LYS-5 is a good test in terms of measuring my level of English' } \\
\hline \multicolumn{2}{|c|}{$\begin{array}{l}\text { Strongly } \\
\text { disagree }\end{array}$} & \multicolumn{2}{|c|}{ Disagree } & \multicolumn{2}{|c|}{ Somewhat agree } & \multicolumn{2}{|c|}{ Agree } & \multicolumn{2}{|c|}{$\begin{array}{l}\text { Strongly } \\
\text { agree }\end{array}$} \\
\hline 13 & $17.6 \%$ & 7 & $9.5 \%$ & 29 & $39.2 \%$ & 20 & $27 \%$ & 5 & $6.8 \%$ \\
\hline \multicolumn{10}{|c|}{ "Because I performed well on the LYS-5, I can perform well in my college classes" } \\
\hline \multicolumn{2}{|c|}{$\begin{array}{l}\text { Strongly } \\
\text { disagree }\end{array}$} & \multicolumn{2}{|c|}{ Disagree } & \multicolumn{2}{|c|}{ Somewhat agree } & \multicolumn{2}{|c|}{ Agree } & \multicolumn{2}{|c|}{$\begin{array}{l}\text { Strongly } \\
\text { agree }\end{array}$} \\
\hline 22 & $30.1 \%$ & 4 & $5.5 \%$ & 27 & $37 \%$ & 18 & $24.7 \%$ & 2 & $2.7 \%$ \\
\hline \multicolumn{10}{|c|}{$\begin{array}{l}\text { "Even though I performed well on the LYS-5, I am having difficulty in my classes } \\
\text { because of English skills" }\end{array}$} \\
\hline \multicolumn{2}{|c|}{$\begin{array}{l}\text { Strongly } \\
\text { disagree }\end{array}$} & \multicolumn{2}{|c|}{ Disagree } & \multicolumn{2}{|c|}{ Somewhat agree } & \multicolumn{2}{|c|}{ Agree } & \multicolumn{2}{|c|}{$\begin{array}{l}\text { Strongly } \\
\text { agree }\end{array}$} \\
\hline 15 & $20.5 \%$ & 5 & $6.8 \%$ & 19 & $26 \%$ & 23 & $31.5 \%$ & 11 & $15.1 \%$ \\
\hline
\end{tabular}

For the first statement, it can be deduced that students did not state high opinion of the LYS-5 whether it is a good test measuring their English level. The evaluations of 29 students (39\%) with 'somewhat agree' displays they thought neither the exam is totally imperfect nor it is efficient in measuring their English level. Likewise, the responses for the second statement also shows a low opinion on the correlation between the LYS-5 exam and their success at their departments. The selection of 'somewhat agree' (27 students with $37 \%$ ) followed by 'strongly disagree' (22 students with $30 \%$ ) expressed their dissatisfaction. For the third statement, when the answers for 'agree' and 'strongly agree' are evaluated together with a total of 34 students $(46.6 \%)$, it can be said that the departmental course success of students do not correlate with their success and achievement in LYS-5.

Table 5. Questionnaire Item 9: "If you had a chance to change LYS-5, what would you add?"

\section{Skills that are not \\ included in LYS-5 examination \\ Skills that are required for LYS-5 exam}

Language Activities
Listening
Speaking
Writing
More Grammar
More Reading
More Vocabulary
More Translation

Frequency
37
48
31
22
15
30
22

Percentile (\%)
50.7
65.8
42.5
30.1
20.5
41.1
30.1

According to the table, the skills that are excluded from the examination have higher rates of demand (speaking with $65.8 \%$, listening with $50.7 \%$, and writing with $42.5 \%$ ) than the required skills for the exam (vocabulary with $41.1 \%$, grammar and translation with $30.1 \%$, and reading with $20.5 \%$ ). However, even though the percentages for excluded skills show the awareness of the ELT freshman students for the necessary language skills, it can also be said the demand for grammar and translation cannot be undervalued; students still overestimate the importance of grammar.

\section{Discussions and Suggestions}

The questionnaire results and analysis provided valuable information for our research questions. The findings profoundly reflect that there are neglected major skills which are 
excluded not only from the LYS-5 exam but also from the studies and in-class practices of the students and teachers as illustrated with the percentages in Table 2. As a result, the students orient their studies only around grammar and vocabulary. This is an obvious indicator that LYS-5 exam is not a comprehensive exam and does not measure the competency in language acquisition.

While the students' major attention was on the skills asked in the examination, according to Table 3 only one fourth of the students found LYS-5 questions useful for their department. However, grammar, vocabulary and reading skills still preserve their importance for students which is believed to be an innate consequence of the exam content. Wrong perceptions and attitudes towards these skills need to be altered through the efforts of the educators as well as redesigning the exam.

According to the Table 4, it can distinctly be stated that the test structure do not measure the English level of the students and correspond with ELT course contents basically. Even though the responses for the first and second statements do not display negative results, the answers express uncertainty with an imbalance in the percentiles. Thus, it is dedicated that the exam content should be reevaluated considering the real needs for a language department. The responses also show that many ELT students do not feel competent enough for their department in their freshman year which also answers the second research question for this study.

It can be stated considering the results given in Table 5 that while most ELT students are aware of the necessary skills for language acquisition, and the number of students who demand the inclusion of neglected skills (especially speaking) is more than the ones who still want to practice existing skills, there still remains the problem of overestimation on grammar which requires huge efforts to change. However, the findings satisfactorily support the main idea of this study. The students' opinions gave the firsthand data to display the importance of the situation. Since the exams and assessments are the major factors that motivate students to study, it is highly essential to decide for the correct examination structure and include the necessary content.

What we suggest in the light of gathered and analyzed data is that for the betterment of the exam structure, the four skills should be emphasized in the same proportion. The exam content should include six skills in total (together with grammar and vocabulary) while the four skills should be the main sub-sections of the test. Besides, the unnecessary question forms should be omitted, and the priority and emphasis given to grammar should be reduced or even given implicitly among other skills, as well. It is supposed the wrong attitudes towards language learning might turn into a positive change through the enhancement of the examination in its accuracy and effectiveness.

\section{Conclusion}

This study includes a limited number of Turkish freshman students from ELT departments of two universities but reflects a general opinion on the LYS-5 examination language skills which should be reevaluated and newly constructed by taking the worldwide accepted English examinations into account. While the sphere of the study is not very wide, it is aimed to contribute to the existing studies, and to emphasize the emergency of the problem.

Not only the English sub-test for the university exam but also the other standardized tests of 
English held in Turkey need to be revised and changed since the tests still follow the old methods. It is believed the indispensable change will first and foremost be helpful for students and language learners. For the correct acquisition of the language, the courses and the assessment tests must include four skills majorly. So as to reach the level of proficiency for the most demanded language of both Turkey and the world, it should be the first step to bring and apply the innovative assessment methods.

\section{References}

Ağazade, A., Caner, H., Hasipoğlu, H. \& Civelek, A. (2013). Turkish University Entrance Test and academic achievement in undergraduate programs: a criterion-related validity study. Procedia - Social and Behavioral Sciences, 116, 4582-4590

Andrews, S., Fullilove, J. \& Wong, Y. (2002). Targetting washback - a case study. System 30, 207-223.

Azar, A. (2010). The Effect of Critical Thinking Dispositions on Students Achievement in Selection and Placement Exam for University in Turkey. The original language of article is English, 7 (1), 61-73

Brown. J. D., \& Christensen T. (1987). Interview: James D. Brown. The Language Teacher, $11(7), 6-10$.

Brown, J.D. (1995a). English language entrance examinations in Japan: Myths and facts. The Language Teacher, 19 (10) 21-26.

Brown, J.D. (2002). English language entrance examinations: A progress report. In Curriculum, innovation, testing and evaluation: Proceedings of the $1^{\text {st }}$ Annual JALT Pan-SIG Conference (95-106). Japan: Kyoto: Institute of Technology.

Brown, J.D. \& Christensen, T. (1987). An interview with J.D. Brown: Analyzing the value, meaning of entrance examinations. The Daily Yomiuri (Educational Supplement, October, 30, 1995), 15.

Brown, J.D. \& Kay, G.S. (1995, November). English language entrance examination at Japanese universities: An interview with James Dean Brown. The Language Teacher, 19 (11), 7-11.

Buck, G. (1988). Testing listening comprehension in Japanese University Entrance Examinations. JALT Journal, 10, 12-42

Cheng, L.Y. (1997). How does washback influence teaching? Implications for Hong Kong. Language and Education, 11, 38-54

Cheng, L.Y. (2005). Changing language teaching through language testing: a washback study. New York: Cambridge University Press

Cheng, L. (2008). The key to success: English language testing in China. Language Testing, $25(1), 15-37$

Demirel, Ö. (1991). Türkiye'de yabancı dil öğretmeni yetiştirmede karşılaşılan güçlükler. (The difficulties faced in teaching language teachers in Turkey). Hacettepe Üniversitesi Ĕgitim Fakültesi Dergisi, 6, 25-29

Dinc, E. \& Dere, I. (2014). Kademeler arası geçiş uygulamalarına yönelik görüşler ve deneyimler. (The opinions and experiences on the applications towards transitions between grades). Adiyaman Universitesi Sosyal Bilimler Enstitüsü Dergisi, 7 (17), 397-423

Gates, S. (1995). Exploiting Washback from Standardized Tests. In Brown J.D. \& Yamashita, S.O. (Eds.) Language Testing in Japan (pp.107-112). Tokyo: Japan Association for Language Teaching.

Hamp-Lyons, L. (1997). Washback, impact and validity: ethical concerns. Language Testing, 14 (3), 295-303 
He, Q. (2001). English language education in China. In Baker, S.J, (Ed.), Language policy: Lessons from global models. Monterey, CA: Monterey Institute of International Studies, 225-31.

Karabulut, A. (2007). Micro level impacts of foreign language test (university entrance examination) in Turkey: a washback study. (MA thesis). ProQuest Information and Learning Company. UMI: 1448691

Kellaghan, T. \& Greaney, V. (1992). Using examinations to improve education: A study of fourteen African countries. Washington, DC: The World Bank.

Kocak, M. (2012). Turk ve Alman egitim sistemlerinde yuksekogretime gecis sureci. The Journal of Language and Linguistic Studies, 8 (1), 148-167.

Kitao, K. (1985). Teaching English in Japan. TEFL in Japan: JALT 10th Anniversary Collected Papers, 27-37

Li, S. (2010). Functional analyses of the problems in non-English majors' writings. US-China Foreign Language, 8 (9), 38-41

National College English Testing Committee. (2006). College English Test-Spoken English Test (CET-SET) Syllabus and Sample Test. Shanghai, China: Shanghai Language Education Press

Phillips, E. (1992). The Effects of Language Anxiety on Students' Oral Test Performance and Attitudes. The Modern Language Journal, 76 (1), 14-26

Qi, L. (2005). Stakeholders' conflicting aims undermine the washback function of a highstakes test. Language Testing, 22 (2), 142-173

Şahin, İ. (2007). Assessment of New Turkish Curriculum for Grade 1 to 5. Elementary Education Online, 6 (2), 284-304

Shohamy, E. (1992). Beyond proficiency testing: A diagnostic feedback testing model for assessing foreign language learning. The Modern Language Learning Journal, 76 (4), $513-521$

Wall, D. (2000). The impact of high-stakes testing on teaching and learning: can this be predicted or controlled? System 28, 499-509

Wall, D. \& Alderson, J.C. (1993). Examining washback: the Sri Lankan impact study. Language Testing, 10, 41-69

Wang, C., Yan, J. \& Liu, B. (2014). An empirical study on washback effects of the internetbased college English test Band 4 in China. English Language Teaching, 7 (6), 26-53

Watanabe, Y. (1996). Does grammar translation come from the entrance examination? Preliminary findings from classroom-based research. Language Testing, 13 (3), 318333.

Y1ldırım, Ö. (2010). Washback Effects of a High-Stakes University Entrance Exam: Effects of the English Section of the University Entrance Exam on Future English Language Teachers in Turkey. The Asian EFL Journal Quarterly, 12 (2), 92-116

Zheng, Y \& Cheng, L (2008). Test Review: College English Test (CET) in China. Language Testing, 409-417. DOI: 10.1177/0265532208092433 